\title{
ENERGETIC POTENTIAL OF Phyllostachys bambusoides AS AN ALTERNATIVE SOURCE OF BIOMASS
}

\author{
Martha Andreia Brand ${ }^{1 *}$, Ailton Leonel Balduino Junior ${ }^{2}$, Gustavo Friederichs ${ }^{3}$, Alexsandro Bayestorff da \\ Cunha $^{1}$ \\ ${ }^{1}$ University of the State of Santa Catarina, Master's Program in Forest Engineering, Lages - SC - Brazil - martha.brand@udesc.br*, \\ alexsandro.cunha@udesc.br \\ ${ }^{2}$ Centro Universitário Facvest, Departamento de Engenharias, Lages - SC - Brazil - balduino.ailton@gmail.com \\ ${ }^{3}$ Bracell Papel e Produtos Florestais S.A - São Paulo - SP - Brazil - gustavofriederichs@ hotmail.com \\ Received for publication: 12/07/2019 - Accepted for publication: 10/12/2019
}

\begin{abstract}
Resumo
Potencial energético de Phyllostachys bambusoides como fonte alternativa de biomassa. No Brasil, o Phyllostachys bambusoides tem sido utilizado para a manufatura de produtos de bambu laminado e paisagismo. Porém, estudos de sua qualidade energética são raros. Assim, este trabalho objetivou determinar a qualidade energética do Phyllostachys bambusoides para uso dos colmos na forma in natura (cavacos) para queima direta, como carvão vegetal e como briquetes. Também foi determinado seu potencial energético por meio do balanço de massa para cada biocombustível sólido (cavacos, briquetes e carvão). As análises foram efetuadas em cinco indivíduos (colmos) com 3 anos de idade, coletados em plantios experimentais em Frei Rogério, SC. Nos colmos foram determinados a umidade recém coletada; massa específica básica; composição química estrutural; análise imediata e poder calorífico superior. No carvão vegetal, produzido em laboratório, foram determinados o rendimento gravimétrico, a densidade relativa aparente, análise imediata e poder calorífico superior. Os briquetes, feitos em briquetadeira laboratorial, foram avaliados por meio de sua densidade aparente e resistência à compressão. Para os colmos, carvão e briquetes foi calculada a densidade energética e construído um fluxograma composto pelo balanço de massa e calculado o potencial de produção de energia térmica para cada $100 \mathrm{~kg}$ de biomassa utilizada na produção de cada biocombustível analisado. A densidade energética dos colmos $\left(1,87 \mathrm{Gcal} . \mathrm{m}^{-3}\right)$, carvão $\left(2,60 \mathrm{Gcal} . \mathrm{m}^{-3}\right)$ e briquetes $\left(4,68 \mathrm{Gcal} . \mathrm{m}^{-3}\right)$ variou significativamente. $\mathrm{O}$ maior potencial energético útil foi dos briquetes $(0,304 \mathrm{Gcal})$, seguido do carvão $(0,184 \mathrm{Gcal})$ e dos colmos $(0,168$ Gcal) para cada $100 \mathrm{~kg}$ de bambu colhido com teor médio de umidade de $35 \%$.

Palavras chaves: bambu; carvão vegetal; briquetes; balanço de massa; potencial energético.
\end{abstract}

\begin{abstract}
In Brazil, Phyllostachys bambusoides has been used for the manufacture of laminated bamboo products and landscaping. However, studies of its energy quality are rare. Thus, this study aimed to determine the energetic quality of Phyllostachys bambusoides for the use of stems in the fresh form (chips) for direct burning, as charcoal and as briquettes. Its energy potential was also determined by mass and energy balance for each solid biofuel (chips, briquettes, and charcoal). The analyzes were carried out on five individuals (shoots) at 3 years of age, collected at experimental plantations in Frei Rogério, SC. In the stems the newly collected moisture was determined; specific gravity; chemical composition; immediate analysis and higher calorific value. In laboratory charcoal, gravimetric yield, apparent relative density, immediate analysis, and higher calorific value were determined. The briquettes, made in the laboratory, were evaluated through their apparent density and compressive strength. For the stems, charcoal, and briquettes the energy density was calculated and a flowchart composed of the mass balance was calculated and the thermal energy production potential for each $100 \mathrm{~kg}$ of biomass used in the production of each biofuel analyzed was calculated. The energy density of stems (1.87 Gcal. $\left.\mathrm{m}^{-3}\right)$, charcoal $\left(2.60 \mathrm{Gcal}^{-3}\right)$, and briquettes $\left(4.68 \mathrm{Gcal} . \mathrm{m}^{-3}\right)$ varied significantly. The highest useful energy potential can be obtained from briquettes $(0.304 \mathrm{Gcal})$, charcoal $(0.184 \mathrm{Gcal})$ followed by stems $(0.168$ Gcal) for each $100 \mathrm{~kg}$ of bamboo harvested with a mean moisture content of $35 \%$.

Keywords: bamboo; charcoal; briquettes; mass balance; energy potential.
\end{abstract}

\section{INTRODUCTION}

Bamboo is the common term applied to a group of 1.250 species of large lignocellulosic grasses that range from $10 \mathrm{~cm}$ to $40 \mathrm{~m}$ in height. These species are daily used by billions of people, mainly as a source of fiber and food in Asia (SCURLOCK et al., 2000). However, recent studies have demonstrated their potential for other purposes, such as the use of bamboo nanofibrils in the plastic and film industries (JUNIOR et al., 2018), in biodegradable composites, in the GLB (glued laminated bamboo), and the furniture sector (CHAOWANA, 2013).

As a biofuel, studies have proven the potential of bamboo species in the production of pellets and briquettes (SETTE JR. et al., 2016; SETTE JR. et al., 2017; JUNIOR et al., 2016; BRAND et al., 2019), and in energy production as fresh material and as coal (JUNIOR et al., 2016; SETTE JR. et al., 2017). Despite these studies with some species, scientific knowledge is still limited when it regards the diversity of existing bamboo

FLORESTA, Curitiba, PR, v. 51, n. 1, p. 201-210, jan/mar 2021.

Brand, M. A. et.al.

ISSN eletrônico 1982-4688

DOI: $10.5380 /$ rf.v51 i1. 67968 
species and, mainly, the possibility of their use as an energy source. This aspect has restricted the full development of bamboo cultivation in Brazil (SETTE JR. et al, 2016).

Bamboo species can be found in hot and cold areas in all states in Brazil, which allows the growth of both native and exotic species throughout the country. The Japanese migration strongly influenced the introduction of spreading bamboo species, like the ones of the genus Phyllostachys. Among the ten most cultivated exotic species in Brazil is the Phyllostachys bambusoides Siebold \& Zucc (TOMBOLATO et al., 2012). This bamboo species is considered medium to large. In Brazil, it has stems with an average diameter of $8 \mathrm{~cm}$ and a height of up to 20 meters. Due to its high mechanical resistance, it is used for building structures and producing glued laminated furniture. The size of the stems and the dark green color of the leaves and stems make it a great plant alternative for open forests (TOMBOLATO et al., 2012). However, studies of its energy application are rare (SCURLOCK et al., 2000; SETTE JR. et al., 2017).

Therefore, bamboo technical information is essential to support decisions related to investments in the cultivation and use of the species for energy. New studies are crucial to expand the base of the bamboo production chain, and to strengthen the use of biomass for energy generation. The solidification of the bamboo production chain becomes a new economic plan for the energy generation segment because the biomass used for power generation in Brazil comes from Eucalyptus and, in some cases, Pinus species or their residues (BRAND et al., 2014). Both genera are the basis of the Brazilian wood production chain.

However, to compete in energy generation with species already being used as biofuels, the stems must be assessed regarding their physical-chemical and energetic properties. In the fresh form, the chips for burning in boilers should have, among other characteristics, low moisture content, medium to high specific gravity, and calorific value similar or superior to the biomasses already being used as biofuel.

According to the SAA Resolution 10 (December 14, 2015) of the State of São Paulo, for domestic use (barbecue), bamboo must generate charcoal with high levels of fixed carbon and bulk density, and reduced levels of moisture content and ashes (SÃO PAULO, 2015). For briquetting, bamboo must produce compacts with low moisture content and high bulk density (BRAND et al., 2019).

Thus, this study aimed to determine the energy quality and the potential for thermal energy production of Phyllostachys bambusoides stems in the fresh form (chips) for direct burning, as charcoal, and as briquettes.

\section{MATERIAL AND METHODS}

\section{Characterization of the fresh stems}

Five three-year-old individuals (stems) of Phyllostachys bambusoides were analyzed. They were collected in a Japanese community's property in Frei Rogério, Santa Catarina, Brazil (27¹3'19.5'S 5044'13.4' $\mathrm{W})$. Even though the species is already being marketed in the region for the production of matchsticks and barbecue sticks, farmers want to reach other markets. In this context, energy generation is one of the alternatives for increasing income in the community where this research project was developed.

Each stem was obtained from an individual to avoid sampling two stems from the same individual in the planting area. DBH and total height measurements were made for each individual (Table 1 and Figure 1 (a)). The exsiccates were sent to the FLOR Herbarium at UFSC. Based on the total height, one-meter-long sections were collected at the base, in the median portion of the total height, and the top of all the stems. The sampling along the stem aimed at covering the variability of the properties over the plant's height. However, the data were treated as the average values obtained per individual, since the objective was to characterize the species energetically and not the variations along the stem. The methodology adopted in this work was based on Junior et al. (2016), who worked with the characterization of Bambusa vulgaris Schrad. ex J.C. Wendl.

Table 1. Dendrometric data of Phyllostachys bambusoides stems.

Tabela 1. Dados dendrométricos dos colmos de Phyllostachys bambusoides.

\begin{tabular}{c|c|c|c|c|c|c}
\hline Individual & $\mathbf{1}$ & $\mathbf{2}$ & $\mathbf{3}$ & $\mathbf{4}$ & $\mathbf{5}$ & Mean \\
\hline DBH $(\mathrm{cm})$ & 8.00 & 7.00 & 8.00 & 9.00 & 8.00 & 8.00 \\
Total height $(\mathrm{m})$ & 15.0 & 13.0 & 12.5 & 16.0 & 15.0 & 14.3 \\
\hline
\end{tabular}

FLORESTA, Curitiba, PR, v. 51, n. 1, p. 201-210, jan/mar 2021. 


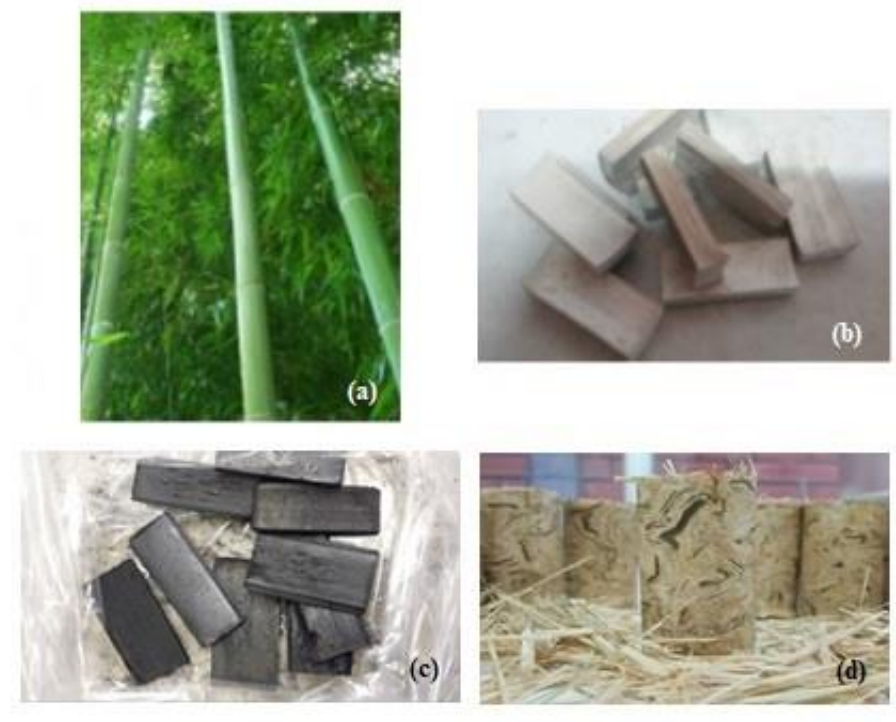

Figure 1. Three-year-old Phyllostachys bambusoides stems in the harvest area (a). Samples used to determine the physical properties and produce charcoal (b). Charcoal (c). Briquettes of the Phyllostachys bambusoides (d)

Figura 1. Colmos de Phyllostachys bambusoides com três anos de idade na área de colheita (a). Corpos-de-prova utilizados para determinação das propriedades físicas e produção do carvão vegetal (b). Carvão vegetal (c). Briquetes de Phyllostachys bambusoides (d)

Samples of $20 \mathrm{~mm}$ wide and $50 \mathrm{~mm}$ long were extracted from the fresh stems, with thickness varying according to the stems' wall (Figure 1 (a)). These samples were used to determine the moisture content on a wet basis (MC), in the recently harvested condition, and the specific gravity (SG) by using the maximum moisture content method, according to NBR 11941 (ABNT, 2003). After obtaining the specimens used to determine the moisture content, the specific gravity, and carbonization, the remaining material was converted into sawdust in a hammer mill. The sawdust was sieved to obtain the fraction retained between the 40 and 60 mesh sieves for chemical and energetic analyses. Table 2 shows the analyses, standards, and experimental design applied to the study.

Table 2. Physical and energetic analyses of Phyllostachys bambusoides stems.

Tabela 2. Determinação das propriedades físicas e energéticas nos colmos de Phyllostachys bambusoides.

\begin{tabular}{|c|c|c|c|c|c|}
\hline Analyzed property & Standard/Source & $\mathbf{N}$ & NP & $\mathbf{R}$ & Total \\
\hline Moisture content & NBR 14929 (ABNT,2003) & 5 & 3 & 3 & 45 \\
\hline Specific gravity & NBR 11941 (ABNT, 2003) & 5 & 3 & 10 & 150 \\
\hline Gross calorific value & DIN 51900 (DIN, 2000) & 5 & 1 & 3 & 15 \\
\hline Proximate analysis & ASTM 1762 (ASTM, 2007) & 5 & 1 & 3 & 15 \\
\hline Structural chemical analysis & NBR 7989 (ABNT, 2010) & 5 & 1 & 4 & 20 \\
\hline
\end{tabular}

Note: Proximate analysis (fixed carbon content; volatiles and ash content); Structural chemical analysis = Lignin contents, ethanol extracts, ethanol-toluene extracts, hot water solubility, and total extracts. $\mathrm{N}=$ Number of individuals analyzed; NP = Number of positions (3: bottom, middle and top; 1 : for mixing the three positions); $\mathrm{R}=$ Number of repetitions for each analyzed property in each position and individual.

\section{Charcoal production}

The same samples used to determine the specific gravity were charred to produce charcoal. They were wrapped in aluminum foil and taken to the muffle oven without air intake. After that, they were burned according to the charring ramp suggested by Junior et al. (2016) (Table 3).

Table 3. Charring ramp used to charcoals of Phyllostachys bambusoides.

Tabela 3. Rampa de carbonização utilizada para a produção de carvão de Phyllostachys bambusoides

\begin{tabular}{cccccccc}
\hline Time $(\mathbf{h})$ & Start & $\mathbf{0 0 : 2 0}$ & $\mathbf{0 1 : 3 0}$ & $\mathbf{0 3 : 0 0}$ & $\mathbf{0 4 : 5 0}$ & $\mathbf{0 6 : 0 0}$ & $\mathbf{0 6 : 3 0}$ \\
\hline Temperature $\left({ }^{\circ} \mathrm{C}\right)$ & 25 & 150 & 200 & 250 & 350 & 450 & 450 \\
Heating rate $\left({ }^{\circ} \mathrm{C} \cdot \mathrm{min}^{-1}\right)$ & - & 7.5 & 2.3 & 1.36 & 1.22 & 1.24 & - \\
\hline
\end{tabular}

FLORESTA, Curitiba, PR, v. 51, n. 1, p. 201-210, jan/mar 2021.

Brand, M. A. et.al.

ISSN eletrônico 1982-4688

DOI: $10.5380 /$ rf.v51 i1. 67968 
After charring, the length, width, and thickness of the specimens were obtained (Figure 1 (c)) and used to calculate the charcoal's volume. The samples' mass was obtained by weighing them on an analytical scale $(0.001 \mathrm{~g})$. The relationship between the mass and the volume of the specimens resulted in the charcoal's bulk density. The gravimetric yield (GY) of the carbonization was calculated by the ratio between the charcoal's dry mass and the absolutely dry mass of the samples before carbonization. The charcoal was then ground and sieved to obtain particles between 40 and 60 mesh, which was used for the following physical and energetic analyses: moisture content (wet basis) (NBR 14929 (ABNT, 2003)), gross calorific value (DIN 51900 (DIN, 2000)), and proximate analysis (ASTM 1762 (ASTM, 2007)).

\section{Bamboo sawdust briquetting}

A laboratory piston briquetting machine (Lippel) with a heating temperature of $120{ }^{\circ} \mathrm{C}$ was used to produce the briquettes. The briquetting time was ten minutes. In the first eight minutes, a pressure of 50 bar was applied. Then, the pressure was raised to 95 bar during the last two minutes, so that the internal packaging of the particles could occur to allow the consolidation of the briquette, according to the methodology also adopted by Brand et al. (2019). The mass of each sample used for briquetting was $50 \mathrm{~g}$. Before briquetting, the moisture content of the sawdust (wet base) was determined after air conditioning (65\% relative humidity, and $\left.22{ }^{\circ} \mathrm{C}\right)$. A total of 25 bamboo briquettes were produced, five for each individual. Each briquette presented nominal dimensions of $35 \mathrm{~mm}$ in diameter and $50 \mathrm{~mm}$ in length.

The particle size distribution of each briquette was $88 \%(44 \mathrm{~g})$ of the mass of the briquette consisting of particles between 3.35 to $15.99 \mathrm{~mm}$ and $12 \%(6 \mathrm{~g})$ with particles between 0.25 to $3.34 \mathrm{~mm}$, according to Brand $e t$ al. (2019). The properties of the briquettes analyzed were the moisture content (wet basis), the bulk density, and the compressive resistance. The gross calorific values used to calculate the energy density of the briquettes (described later) were the same used for the fresh material.

The briquettes' bulk density was determined by the relationship between their masses (obtained by weighing them on an analytical scale $(0.001 \mathrm{~g})$ ) and volumes before the compression resistance test was performed. The diametrical compressive resistance test was performed in a universal testing machine EMIC model DL $300 \mathrm{KN}$, according to NBR 7222 (ABNT, 2011), with a compression speed of $2 \mathrm{~mm} \cdot \mathrm{min}^{-1}$, to obtain a maximum force supported by the briquette until its total rupture. After that, the briquettes were fragmented to obtain the moisture content on a wet basis (ABNT, 2003).

\section{Energy potential through mass and energy balance and statistical treatment}

For each form (fresh stems, briquettes, and charcoal), the net energy density (NED) was determined by the product of the specific gravity and the net calorific value (NCV), calculated according to Equation 1. For the fresh stems, it was used the specific gravity, while for the briquettes and charcoal it was used the bulk density.

$$
N C V=L C V \times\left[\frac{(100-M C)}{100}\right]-6 \times M C \quad \text { Equation } 1
$$

Where: $\mathrm{NCV}=$ Net calorific value $(\mathrm{kcal} / \mathrm{kg}) ; \mathrm{LCV}=$ Lower calorific value, calculated from the gross calorific value and the equation: $L C V=G C V-\left[600 \times\left(\frac{9 \times H}{100}\right)\right]$, where $\mathrm{H}=6 \%$; $\mathrm{MC}=$ Moisture content on wet basis (fresh stems after harvested; charcoal after charring and temperature stabilization; briquettes after stabilization and compressive resistance test).

To determine the bamboo's energy potential under the different forms of use of solid biofuel, a flowchart based on the mass balance was built, considering as input the bamboo mass with moisture content determined in the newly harvested state $(100 \mathrm{~kg}$ ). This mass went through technological routes for the use of biofuel (chips, briquettes, and charcoal). In each technological route, the final moisture content of the fuel, the net calorific value, and the charcoal's gravimetric yield were considered. Using equations 2,3 , and 4, the potential for thermal energy production in Gcal (Pe) was calculated for each type of solid fuel, from $100 \mathrm{~kg}$ of bamboo harvested in the field (Figure 2).

$$
P e=M c x P C L
$$

Equation 2

Where: $\mathrm{Pe}=$ Thermal energy potential (Gcal); $\mathrm{Mc}=$ Biofuel's mass with final use's moisture content, from 100 $\mathrm{kg}$ of biomass with recently harvested moisture content $(\mathrm{kg})$ (Equation 3 or 4); NCV = Net calorific value of the biofuel (chips, briquettes, and charcoal).

$$
M c=100-M a \quad \text { Equation } 3
$$

Where: Mc = Biofuel's mass with final use's moisture content, from $100 \mathrm{~kg}$ of biomass with recently harvested moisture content $(\mathrm{kg}) ; 100=$ humid mass of the biofuel recently harvested $(\mathrm{kg}) ; \mathrm{Ma}=$ water mass removed during the biofuel conversion process, up to the final moisture content of use of the biofuel.

Considering only the charcoal, the gravimetric yield (GY) must be taken into account when calculating the $\mathrm{Mc}$ as to add the final charcoal's moisture content only after defining the mass of charcoal produced $(0 \%$ moisture content), (Equation 4).

FLORESTA, Curitiba, PR, v. 51, n. 1, p. 201-210, jan/mar 2021. 
$M c=\left[(100-M a) x\left(\frac{G Y}{100}\right)\right]+$ MCcharcoal

Equation 4

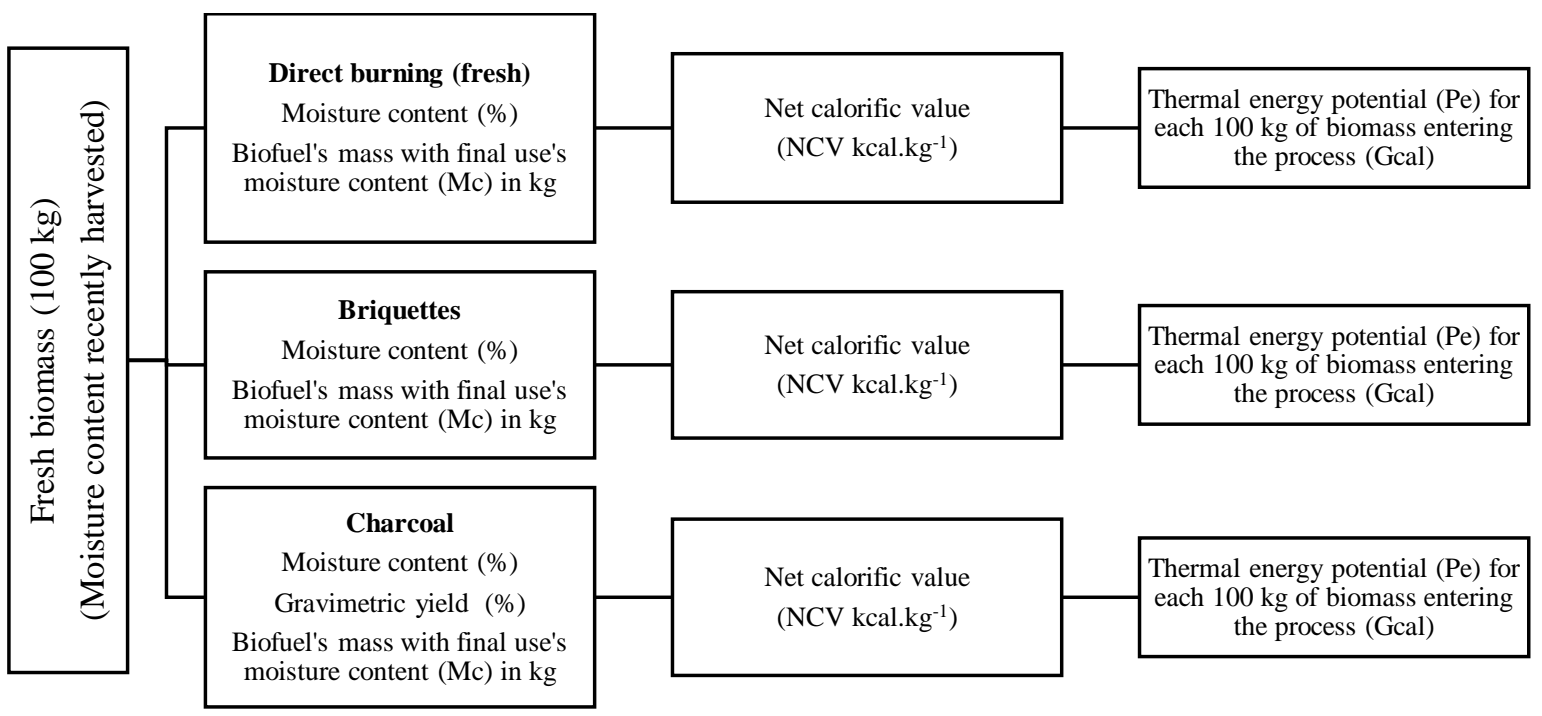

Figure 2. Flowchart to obtain thermal energy production from the solid biofuel.

Figura 2. Fluxograma para obtenção da produção de energia térmica a partir de cada forma de uso do biocombustível sólido.

For all the analyzed properties, the averages of each individual and the general mean and standard deviation of all individuals were obtained. The fresh stems, the briquettes, and the charcoal were considered as treatments. Test $\mathrm{F}$ was applied to verify the variation in energy density between treatments, and the Tukey test was applied at a $5 \%$ probability of error.

\section{RESULTS}

The physical, chemical and energetic properties of the fresh stems, the charcoal, and the briquettes of $P$. bambusoides are presented in Table 4. Table 5 shows the results obtained from the literature regarding the analyzed properties of stems and charcoal produced with P. bambusoides, Eucalyptus urgorandis, and other bamboo species. Moreover, the flowchart in Figure 3 shows the thermal energy potential obtained from the fresh stems, the charcoal, and the briquettes of P. bambusoides.

Table 4. Physical, chemical, and energetic properties of fresh stems, charcoal, and briquettes of P. bambusoides. Tabela 4. Propriedades físicas, químicas e energéticas dos colmos in natura, do carvão vegetal e dos briquetes de P. bambusoides.

\begin{tabular}{|c|c|c|c|c|c|c|}
\hline \multirow{2}{*}{ Fresh stems } & \multicolumn{5}{|c|}{ Individuals } & \multirow{2}{*}{$\begin{array}{c}\text { Mean (Standard } \\
\text { deviation) }\end{array}$} \\
\hline & 1 & 2 & 3 & 4 & 5 & \\
\hline $\mathrm{MC}(\%)$ & 34 & 36 & 37 & 36 & 36 & $35(2.120)$ \\
\hline $\mathrm{SG}\left(\mathrm{kg} \cdot \mathrm{m}^{-3}\right)$ & 717 & 717 & 684 & 719 & 758 & $719(0.046)$ \\
\hline $\operatorname{ETE}(\%)$ & 5.15 & 5.22 & 5.27 & 5.43 & 5.44 & $5.3(0.247)$ \\
\hline $\operatorname{DEE}(\%)$ & 5.31 & 5.54 & 5.46 & 5.66 & 5.42 & $5.48(0.456)$ \\
\hline $\mathrm{HW}(\%)$ & 5.56 & 5.51 & 5.30 & 5.34 & 5.39 & $5.42(0.371)$ \\
\hline $\mathrm{TE}(\%)$ & 16.02 & 16.48 & 16.03 & 16.42 & 16.25 & $16.24(0.731)$ \\
\hline $\mathrm{L}(\%)$ & 25.59 & 25.52 & 25.55 & 25.52 & 25.51 & $25.54(0.782)$ \\
\hline $\mathrm{VM}(\%)$ & 81.35 & 82.35 & 81.55 & 81.73 & 82.54 & $81.88(0.012)$ \\
\hline $\mathrm{FC}(\%)$ & 17.57 & 17.33 & 17.24 & 17.72 & 16.52 & $17.28(0.012)$ \\
\hline $\mathrm{AC}(\%)$ & 1.08 & 0.71 & 1.21 & 0.54 & 0.94 & $0.9(0.003)$ \\
\hline 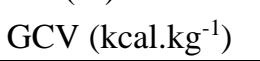 & 4758 & 4595 & 4757 & 4638 & 4723 & 4694 (106) \\
\hline NED $\left(\right.$ Gcal.m $\left.{ }^{-3}\right)$ & 1.94 & 1.82 & 1.78 & 1.84 & 1.97 & $1.87 \mathrm{C}$ \\
\hline Charcoal & 1 & 2 & 3 & 4 & 5 & Mean \\
\hline
\end{tabular}

FLORESTA, Curitiba, PR, v. 51, n. 1, p. 201-210, jan/mar 2021.

Brand, M. A. et.al.

ISSN eletrônico 1982-4688

DOI: $10.5380 /$ rf.v51 i1. 67968 


\begin{tabular}{|c|c|c|c|c|c|c|}
\hline MC (\%) & 5.56 & 5.45 & 6.13 & 2.80 & 2.61 & 4.51 \\
\hline $\mathrm{BC}_{\mathrm{c}}\left(\mathrm{kg} \cdot \mathrm{m}^{-3}\right)$ & 314 & 367 & 336 & 401 & 419 & $367(0.020)$ \\
\hline GY $(\%)$ & 31.88 & 34.17 & 32.75 & 34.06 & 33.91 & $33.35(0.056)$ \\
\hline $\mathrm{VM}(\%)$ & 27.07 & 29.53 & 26.20 & 27.05 & 26.48 & $27.26(0.012)$ \\
\hline $\mathrm{FC}(\%)$ & 71.60 & 69.49 & 72.03 & 70.90 & 71.41 & $71.09(0.020)$ \\
\hline $\mathrm{AC}(\%)$ & 1.33 & 0.98 & 1.77 & 2.06 & 2.11 & $1.65(0.020)$ \\
\hline GCV (kcal.kg $\left.{ }^{-1}\right)$ & 7747 & 7727 & 7582 & 7356 & 7525 & 7587 (307) \\
\hline NED $\left(\right.$ Gcal.m $\left.{ }^{-3}\right)$ & 2.24 & 2,61 & 2.32 & 2,80 & 3.00 & $2.60 \mathrm{~B}$ \\
\hline Briquettes & 1 & 2 & 3 & 4 & 5 & Mean \\
\hline MC sawdust (\%) & 11 & 11 & 11 & 11 & 11 & $11(0.001)$ \\
\hline MC briquettes (\%) & 6 & 8 & 8 & 8 & 8 & $7(0.011)$ \\
\hline $\mathrm{BD}_{\mathrm{b}}\left(\mathrm{kg} \cdot \mathrm{m}^{-3}\right)$ & 1199 & 1176 & 1178 & 1181 & 1115 & $1170(0.034)$ \\
\hline $\mathrm{CR}(\mathrm{MPa})$ & 5.19 & 4.57 & 4.94 & 4.88 & 3.81 & $4.68(0.645)$ \\
\hline $\operatorname{NED}\left(\right.$ Gcal.m $\left.{ }^{-3}\right)$ & 4.98 & 4.58 & 4.74 & 4.62 & 4.46 & $4.68 \mathrm{~A}$ \\
\hline
\end{tabular}

Note: $\mathrm{MC}=$ moisture content on wet basis; $\mathrm{SG}=$ specific gravity; ETE = ethanol-toluene extractives on dry basis; DEE = dry ethanol extractives; HW = extractives in hot water on dry basis; TE = total extractives on dry basis; $\mathrm{L}=\mathrm{Klason}$ 's lignin content; FC = fixed carbon content; $\mathrm{VM}=$ volatile-matter content; $\mathrm{AC}=$ ash content; $\mathrm{GCV}=$ gross calorific value; $\mathrm{NED}=$ net energy density; $\mathrm{BDc}=$ charcoal's bulk density; GY = gravimetric yield; $\mathrm{BDb}=$ briquettes' bulk density; $\mathrm{CR}=$ compressive resistance. Averages followed by the same letter CAPITAL LETTER. NED between fresh stems, charcoal and briquettes indicate that there was no significant variation between individuals at a level of $95 \%$ for the Tukey Test.

Table 5. Chemical and energetic properties of the stems and charcoal of bamboo and Eucalyptus species from the literature.

Tabela 5. Propriedades químicas e energéticas de colmos e do carvão vegetal de espécies de bambu e de Eucalyptus na literatura

\begin{tabular}{|c|c|c|c|c|}
\hline Stems (fresh) & Eucalyptus urograndis & P. bambusoides & Phyllostachys sp. & Bambusa vulgaris \\
\hline ETE $(\%)$ & & & 3.4 a $4.6^{(2)} 2.6$ e $4.6^{(4)}$ & \\
\hline $\mathrm{EE}(\%)$ & & $1.1^{(2)}$ & & \\
\hline $\mathrm{TE}(\%)$ & $1.15^{(5)}$ & & & $16.26^{(3)}$ \\
\hline $\mathrm{L}(\%)$ & $30.2^{(5)}$ & $25.5^{(2)}$ & $\begin{array}{l}23.8 \text { a } 26.1^{(2)} \\
23.6 \text { a } 26.1^{(4)}\end{array}$ & $25.76^{(3)}$ \\
\hline $\mathrm{VM}(\%)$ & $82.2^{(1)}$ & $83.52^{(2)}$ & $81.50^{(6)}$ & $74.7^{(1)} ; 82.25^{(3)}$ \\
\hline $\mathrm{FC}(\%)$ & $17.5^{(1)}$ & $15.90^{(2)}$ & $17.60^{(6)}$ & $22.8^{(1)} ; 15.26^{(3)}$ \\
\hline $\mathrm{AC}(\%)$ & $0.3^{(1)} ; 0.3^{(5)}$ & $0.59^{(2)}$ & 1.3 a $2.0^{(4)} 0.90^{(6)}$ & $2.5^{(1) ;} 2.49^{(3)}$ \\
\hline GCV (kcal. $\left.\mathrm{kg}^{-1}\right)$ & $4658^{(1)}$ & $4560^{(2)}$ & $4404^{(6)}$ & $4663^{(1)} ; 4585^{(3)}$ \\
\hline $\mathrm{ED}\left(\right.$ Gcal.m $\left.\mathrm{m}^{-3}\right)$ & $2.17^{(1)}$ & & $2.11^{(6)}$ & $2.16^{(1)}$ \\
\hline Charcoal & Eucalyptus urograndis & & & Bambusa vulgaris \\
\hline $\mathrm{BD}\left(\mathrm{kg} \cdot \mathrm{m}^{-3}\right)$ & & & $400^{(6)}$ & $376^{(3)}$ \\
\hline GY $(\%)$ & $30.8^{(1)}$ & & $32.70^{(6)}$ & $34.7^{(1)} ; 36.4^{(3)}$ \\
\hline $\mathrm{VM}(\%)$ & $29.1^{(1)}$ & & $25.40^{(6)}$ & $23.6^{(1)}$ \\
\hline $\mathrm{FC}(\%)$ & $70.4^{(1)}$ & & $69.40^{(6)}$ & $73.4^{(1)}$ \\
\hline $\mathrm{AC}(\%)$ & $0.4^{(1)}$ & & & $3.0^{(1)}$ \\
\hline GCV (kcal. $\left.\mathrm{kg}^{-1}\right)$ & $6670^{(1)}$ & & $6775^{(6)}$ & $6777^{(1)} ; 7431^{(3)}$ \\
\hline $\mathrm{ED}\left(\mathrm{Gcal}_{\mathrm{m}} \mathrm{m}^{-3}\right)$ & $2.40^{(1)}$ & & $2.72^{(6)}$ & $2.30^{(1)}$ \\
\hline
\end{tabular}

Note 1: ETE = ethanol-toluene extractives $; \mathrm{EE}=$ extractives in ethanol; $\mathrm{TE}=$ total extractives; $\mathrm{L}=$ lignin content; $\mathrm{FC}=$ fixed carbon content; $\mathrm{VM}=$ volatile-matter content; $\mathrm{AC}=$ ash content $\mathrm{GCV}=$ gross calorific value; $\mathrm{NED}=$ net energy density; $\mathrm{BD}=$ charcoal's bulk density; GY = gravimetric yield.

Note 2: (1) De Souza Santos et al. (2016): Bambusa vulgaris (age 5) and Eucalyptus urograndis (age 6); (2) Scurlock et al. (2000): Phyllostachys bambusoides (age 4.5); (3) Junior et al. (2016): Bambusa vulgaris (age 3); (4) Chaowana (2013); (5) De Morais et al. (2017): Eucalyptus urograndis (age 3). (6) SETTE JR et al. (2017): Phyllostachys aurea culms and charcoal (age 5).

FLORESTA, Curitiba, PR, v. 51, n. 1, p. 201-210, jan/mar 2021. 


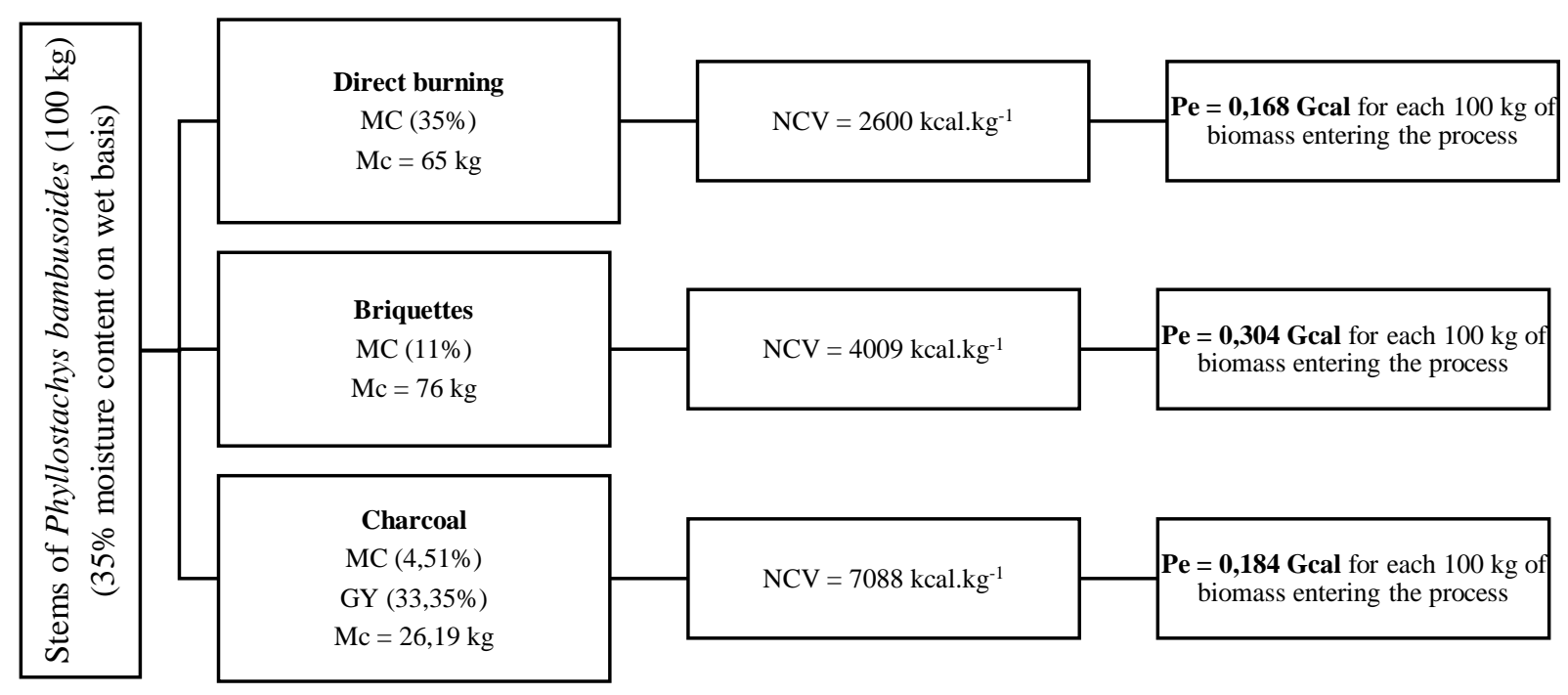

Figure 3. Flowchart of the energetic potential of Phyllostachys bambusoides stems to be used in direct burning, as briquettes, and as charcoal.

Figura 3. Fluxograma de potencial energético dos colmos de Phyllostachys bambusoides para uso na queima direta, como briquetes e como carvão vegetal

\section{DISCUSSION}

\section{Bamboo stems' energetic quality}

The moisture content of the newly harvested bamboo stems was close to the expected value used for energy generation, which is $30 \%$ on a wet basis. This is an advantage when compared with wood species used as an energy resource. Bamboo begins its aging process between 3 to 4 years. This process is characterized by the thickening of the fiber walls and parenchyma cells due to the deposition of additional lamellae in the cell wall layers followed by lignification. It increases its density and resistance (RUSCH et al. 2018), and it probably decreases its hygroscopicity, which contributes to the reduction of the moisture content of the freshly cut stems and explains the moisture content close to the fiber saturation point observed in this study.

According to Brand (2013), the wood of Pinus taeda and Eucalyptus dunnii used as biofuels presented moisture contents on a wet basis that varied between 55 to $65 \%$ (pine) and 50 to $58 \%$ (eucalyptus) shortly after the harvest. Scurlock et al. (2000), when analyzing stems of P. bambusoides, found moisture contents from $9 \%$ to $23 \%$ on a wet basis.

Thus, this bamboo species will have higher energetic efficiency when used for direct burning in boilers because they require less mass to be converted into steam or electrical energy units. This advantage is reinforced by its specific gravity, which can be classified between medium and high for the P. bambusoides. A classification which was based on the criteria of the Forest Products' Laboratory (LPF, 2019). It establishes the high specific gravity as being greater than $0.72 \mathrm{~g} . \mathrm{cm}^{-3}$ in wood. For bamboos in general, the specific gravity varies from 0.4 to 0.9 g. $\mathrm{cm}^{-3}$, depending on the anatomical structure (CHAOWANA, 2013). Also, the bamboo's density was higher than the values found by Protásio et al. (2011) for Eucalyptus sp., which ranged from 0.471 g.cm ${ }^{-3}$ to 0.619 g.cm ${ }^{-}$ ${ }^{3}$. Considering the energy use in any form, a high specific gravity is highly desirable because it increases the energy density of the biofuel.

Regarding the chemical composition of the P. bambusoides stems, the values of ethanol and ethanoltoluene extractives were high when compared to the literature for the same species or species of the same genus (Table 5). These variations may be linked to the age of the stems and to the region and weather where the plants were grown. Despite being from a different genus, Bambusa vulgaris (age 3) (JUNIOR et al., 2016) presented similar values of total extractives and lignin (Table 5). Also, the lignin contents of the same species and species of the same genus from the literature were similar to those obtained in this study.

The main components of lignocellulosic bamboos are cellulose, poliosis, and lignin. They add up to more than $90 \%$ of the total mass, with low molecular weight compounds (resins, tannins, waxes, and inorganic salts) representing up to $10 \%$ of its mass. When comparing the bamboo with wood species, its chemical composition is similar to the Eudicotyledons Angiosperms, except for the higher ash content presented in the bamboo (CHAOWANA, 2013). This fact was also confirmed in this work. Extractive and ash contents were higher in the bamboo, while the lignin content was higher in the Eucalyptus urograndis used for comparison (Table 5)

FLORESTA, Curitiba, PR, v. 51, n. 1, p. 201-210, jan/mar 2021.

Brand, M. A. et.al.

ISSN eletrônico 1982-4688

DOI: 10.5380/rf.v51 i1. 67968 
However, based on Table 5 and the results, the Phyllostachys bambusoides resembles both the Bambusa vulagaris and the Eucalytpus urograndis when comparing their gross calorific values, despite the differences observed in their structural chemical compositions. Therefore, the energy potential per unit mass of different bamboo species is the same as one Eucalyptus species. There may be only differences in the energy density when the specific gravity of each species is taken into account.

The flammability, combustibility, and residence time during combustion of the Phyllostachys bambusoides will be similar to the Eucalyptus urograndis due to the similar average fixed carbon and volatile material contents of both species. The results obtained in this study were also similar to those of the same species but age 4.5 (Table 5). However, bamboo species, in general, will have a greater potential to generate waste after burning (ashes) than wood species due to their higher ash contents. Also, they may present worse problems of corrosion, deposition, and incrustations in burners and boilers than wood because the bamboo ashes are composed mainly of silica, calcium, and potassium (CHAOWANA, 2013).

\section{Charcoal's quality for cooking}

The Phyllostachys bambusoides presented high bulk density, which was similar to the one found in the literature for the charcoal of three-year-old Bambusa vulgaris in the same experimental conditions (Table 5). The charcoal's bulk density should be as high as possible, as this property contributes to the increase in energy density. Considering its use for cooking, this property was considered one of the three quality requirements that customers considered most important for charcoal used for barbecue in a study by Dias Júnior et al. (2015).

The gravimetric yield (GY) was higher than the one presented by De Souza Santos et al. (2016) when studying the Eucalyptus urograndis charring and lower than the Bambusa vulgaris one (Table 5) under the same conditions and charring temperature. This property is influenced by charring parameters such as temperature, time, and heating rate. Therefore, although high values are desired because they represent a greater amount of charcoal produced from the same amount of wood, a high yield may not mean charcoal with high quality. The bulk density must be evaluated along with other energetic properties as the proximate analysis and the gross calorific value.

Regarding the proximate analysis, high-quality charcoal used for cooking must have a fixed carbon content higher than $73 \%$, and moisture and ash contents lower than 5 and 1.5\%, respectively (SÃO PAULO, 2015). In this context, the Phyllostachys bambusoides charcoal would only meet the accepted moisture content criteria under the adopted charring conditions However, the carbonization parameters can be adjusted to achieve the desired indexes.

Comparing the results to the literature, the analyzed charcoal had a higher fixed carbon content than the Eucalyptus urograndis charcoal, and lower ash content than the one obtained from Bambusa vulgaris. Phyllostachys bambusoides charcoal showed better quality than 12 commercial brands of wood charcoal for home use analyzed by Brand et al. (2015). The gross calorific value was higher than the ones observed in the literature for Eucalyptus urograndis, Bambusa vulgaris, and the 12 commercial charcoal brands analyzed by Brand et al. (2015).

Therefore, the Phyllostachys bambusoides charcoal can be successfully introduced to the domestic charcoal market as long as the carbonization parameters are adjusted to increase the fixed carbon content of the final product.

\section{Bamboo briquettes' properties}

The sawdust's moisture content before briquetting was homogeneous for all the analyzed individuals (Table 4), and it was considered adequate for the briquetting process. After briquetting, there was a moisture content reduction between 3 to $4 \%$. The bulk density of the briquettes was higher than the one presented by Protásio et al. (2011), who obtained values of $946 \mathrm{~kg} \cdot \mathrm{m}^{-3}$ when studying eucalyptus sawdust briquettes with the same pressing temperature and with $15 \mathrm{Mpa}$ pressure. Briquettes' bulk density influences the energy density as evidenced by Brand et al. (2019). The authors obtained a Pearson's correction coefficient R2 of 0.95 between the bulk density and the energy density of briquettes produced with different bamboo species. In the same study, the $\mathrm{R} 2$ between the gross calorific value and the energy density was 0.55 , proving that the bulk density contributes more significantly to the increase in energy density.

Moreover, the compressive resistance was lower than the one showed by Dias Júnior et al. (2014), who found values of 7.884 MPa for briquettes composed of $100 \%$ bamboo sawdust (Bambusa sp.). On the other hand, Protásio et al. (2011) presented a compressive resistance of $0.82 \mathrm{MPa}$ when studying eucalyptus sawdust, which is higher than the one found for the Phyllostcahys bambusoides briquettes. The differences in compressive resistance among briquettes produced with different materials are due to variations in the briquettes' bulk density. It may also be related to parameters of the production process such as temperature, time, and pressure applied. Dias Júnior et al. (2014) and Brand et al. (2019) established a strong and positive relationship between the bulk density and the compressive resistance of briquettes. When applying the adjusted equation $\left(\mathrm{R}^{2}=0.46\right)$ by Brand et al. (2019), briquettes with $1170 \mathrm{~kg} \cdot \mathrm{m}^{-3}$ should have a compressive resistance of around $5.21 \mathrm{MPa}$, which is close

FLORESTA, Curitiba, PR, v. 51, n. 1, p. 201-210, jan/mar 2021. 
to the one found in this study. In this sense, the analyzed bamboo briquettes can be considered to have excellent quality. They constitute a technically viable alternative for the multiple uses of the species.

\section{The energetic potential of Phyllostachys bambusoides stems}

Comparing the results obtained from the fresh stems, the briquettes, and the charcoal, it is clear that the briquettes presented the highest energy density due to their high bulk density. The charcoal presented higher energy density than the fresh material because of its greater net calorific value, which is a consequence of its low moisture content and higher gross calorific power. Despite the high specific gravity of the fresh stems, the higher moisture content of the newly harvested biomass reduced the net energy density of the fuel. The energy density values of the fresh stems were lower than those observed by De Souza Santos et al. (2016) for Eucalyptus urograndis and Bambusa vulgaris, and larger than those registered for the charcoal produced with the same species (Table 5).

When assessing the potential for thermal energy generation (Figure 3), the briquettes are the most efficient form of energy conversion, followed by charcoal. This can be explained by the fact that the inclusion of the moisture content and the gravimetric yield (charcoal only) in the analysis of the $100 \mathrm{~kg}$ input of biomass in the energy conversion processes makes the compaction process the most efficient during the steps of the mass balance. Thus, the increase in density combined with the reduction of the moisture content turned the bamboo briquettes into a successful energy source. On the other hand, the higher net and gross calorific power of the charcoal did not compensate for the mass loss that occurred during charring, which reduced the energetic potential of this biofuel.

\section{CONCLUSIONS}

This study aimed to determine the energy quality and the potential for thermal energy production of Phyllostachys bambusoides stems. Also, it aimed to compare their properties with Eucalyptus species and other bamboo species to subsidize information for the expansion of the raw-material base used for bioenergy generation. Thus, it can be concluded that:

- Compared to other biomass sources, the freshly harvested Phyllostachys bambusoides stems had a lower moisture content than the Eucalyptus and the lower ash content than the other bamboo species as advantages. The other physical and energetic properties were similar to the biomasses traditionally used for power generation.

- The charcoal did not meet the existing national quality criteria to be used for cooking. However, it presented chemical and energetic properties similar to those obtained for wood charcoals marketed for barbecue in the country. Adjustments in the charring parameters must be studied to improve the energetic properties of this bamboo charcoal.

- Considering the net energetic potential that can be obtained from the bamboo, briquettes presented themselves as the most efficient way of using the Phyllostachys bambusoides for available thermal energy generation because they showed the highest energy densities.

\section{ACKNOWLEDGMENTS}

To CNPq, Associação Catarinense do Bambu - Bambu- SC and the Federal University of Santa Catarina. Research project: "Technologies for the sustainable development of the bamboo production chain in southern Brazil”, BambuSul / CNPq - n ${ }^{\circ} 457726$ / 2013-0 9, MCTI / AÇÃO TRANSVERSAL / CNPq N 66/2013 and CNPq. (Case 303063 / 2017-3 - PQ - 2017) and Research Support Foundation of the State of Santa Catarina (FAPESC).

\section{REFERENCES}

AMERICAN SOCIETY FOR TESTING AND MATERIAL (ASTM). ASTM 1762: Standard Test Method for Chemical Analysis of Wood Charcoal. West Conshohocken, PA., 2013.

ASSOCIAÇÃO BRASILEIRA DE NORMAS TÉCNICAS. NBR 7222: Concreto e argamassa — Determinação da resistência à tração por compressão diametral de corpos de prova cilíndricos. Rio de Janeiro, 2011.

ASSOCIAÇÃO BRASILEIRA DE NORMAS TÉCNICAS. NBR 14929: Madeira - Determinação do teor de umidade de cavacos - Método por secagem em estufa. Rio de Janeiro, 2003.

ASSOCIAÇÃO BRASILEIRA DE NORMAS TÉCNICAS. NBR 7989: Pasta celulósica e madeira - Determinação de lignina insolúvel em ácido. Rio de Janeiro, 2010.

ASSOCIAÇÃO BRASILEIRA DE NORMAS TÉCNICAS. NBR 11941: Madeira: Determinação da Densidade básica. Rio de Janeiro, 2003.

FLORESTA, Curitiba, PR, v. 51, n. 1, p. 201-210, jan/mar 2021. 
BRAND, M. A.; JUNIOR, A. L. B.; NONES, D. L.; GAA, A. Z. N. Potential of bamboo species for the production of briquettes. Pesquisa Agropecuária Tropical, v. 49, p. 1-7, 2019.

BRAND, M. A.; STÄHELIN, T. S.F.; FERREIRA, J.C.; NEVES, M.D. Produção de biomassa para geração de energia em povoamentos de Pinus taeda L. com diferentes idades. Revista Árvore, Lavras, v. 38, n. 2, p. 353-360, 2014.

BRAND, M.A. Influência da espécie na qualidade da biomassa florestal sob estocagem, para geração de energia. Ambiência, Irati, v. 9, n. 3, p. 461-474, 2013.

BRAND, M. A.; ALMADA RODRIGUES, A.; DE OLIVEIRA, A.; SILVEIRA MACHADO, M.; ZEN, L. R. Qualidade do carvão vegetal para o consumo doméstico comercializado na região serrana sul de Santa Catarina. Revista Árvore, Lavras, v. 39, n.6, p.1165-1173, 2015.

CHAOWANA, P. Bamboo: An alternative raw material for wood and wood-based composites. Journal of Materials Science Research, Ontário, v. 2, n. 2, p. 90, 2013.

DEUTSCHES INSTITUT FÜR NORMUNG - DIN. DIN 51900: Determining the gross calorific value of solid and liquid fuels using the bomb calorimeter, and calculation of net calorific value. Berlim, 2000.

DIAS JÚNIOR, A. F.; ANDRADE, C. R.; BRITO, J. O.; MILAN, M. Desdobramento da função qualidade (QFD) na avaliação da qualidade do carvão vegetal utilizado para cocção de alimentos. Floresta e Ambiente, Rio de Janeiro, v.22, n.2, p. 262-270, 2015.

DIAS JÚNIOR, A.F.; DE ANDRADE, A.M.; DA COSTA JÚNIOR, D.S. Caracterização de briquetes produzidos com resíduos agroflorestais. Pesquisa Florestal Brasileira, Colombo, v. 34, n. 79, p. 225-234, 2014.

DE MORAIS, P. H. D.; JÚNIOR, D. L.; COLODETTE, J. L.; DA COSTA MORAIS, E. H.; JARDIM, C. M. Influência da idade de corte de clones de Eucalyptus grandis e híbridos de Eucalyptus grandis x Eucalyptus urophylla na composição química da madeira e polpação kraft. Ciência Florestal, Santa Maria, v. 27, n. 1, p. 237-248, 2017.

DE SOUZA SANTOS, D. R.; JUNIOR, C. R. S.; DA SILVA, M. F.; YAMAJI, F. M.; DE ARAÚJO ALMEIDA, R. Potencial de espécies de Bambu como fonte energética. Scientia Forestalis, Piracicaba, v. 44, n. 111, p. 751-758, 2016.

JUNIOR, B.L.A.; BALDUINO, T.Y.; FRIEDERICHS, G.; CUNHA, A.B.; BRAND, M.A. Energetic potential of bamboo culms for industrial and domestic use in Southern Brazil. Ciência Rural, Santa Maria, v. 46, n. 11, 2016.

JUNIOR, M. G.; TEIXEIRA, F. G.; TONOLI, G. H. D. Effect of the nano-fibrillation of bamboo pulp on the thermal, structural, mechanical, and physical properties of nanocomposites based on starch/poly (vinyl alcohol) blend. Cellulose, Zurique, v. 25, n. 3, p. 1823-1849, 2018.

LABORATÓRIO DE PRODUTOS FLORESTAIS. Banco de Dados de Espécies de Madeiras Brasileiras. Brasília: Serviço Florestal Brasileiro. Available from: < http:// http://sistemas.florestal.gov.br/madeirasdobrasil/pesquisa.php>. Accessed on: April 24, 2019.

PROTÁSIO T.D.P.; ALVES, I.C.N.; TRUGILHO, P.F.; SILVA, V.O.; BALIZA, A.E.R. Compactação de biomassa vegetal visando à produção de biocombustíveis sólidos. Pesquisa Florestal Brasileira, Colombo, v. 31, n. 68, p. 273, 2011.

RUSCH, F.; HILLIG, É.; BORDIGNON CEOLIN, G. Anatomia de hastes adultas de bambu: uma revisão. Pesquisa Florestal Brasileira, Colombo, v. 38, p. 1-10 2018.

SCURLOCK, J.M.O.; DAYTON, D.C.; HAMES, B. Bamboo: An overlooked biomass resource? Biomass and bioenergy, Manchester, v. 19, n. 4, p. 229-244, 2000.

SETTE JR, C. R.; DE CASTRO, P.; FREITAS, V. P.; YAMAJI, F. M.; DE ARAÚJO ALMEIDA, R. Production and characterization of bamboo pellets. Bioscience Journal, Uberlandia, v. 32, n. 4, 2016.

SETTE, J., LIMA, P. A. F., LOPES, D. M. M., BARBOSA, P. V. G., CONEGLIAN, A., \& ALMEIDA, R. D. A. Characterization of biomass, charcoal, and briquette of Phyllostachys aurea Carr. ex A. \& C. Rivière. Scientia Forestalis, Piracicaba, v. 45, n. 116, p. 619-628, 2017.

SÃO PAULO (Estado). Secretaria de Agricultura e Abastecimento de São Paulo.Resoluçãon ${ }^{\circ} 10$ SAA de14 de dezembro de 2015. São Paulo:2015. Available from: http://www.codeagro.agricultura.sp.gov.br/arquivos/selo/SAA\%2040\%20Carvao\%20Vegetal\%202015.pdf. Accessed on: April 15, 2019.

TOMBOLATO, A.F.C.; GRECO, T.M.; PINTO, M.M. Dez espécies de bambus exóticos mais comuns no paisagismo no Brasil. Revista Brasileira de Horticultura Ornamental, Juiz de Fora, v. 18, n. 2, p. 105-114, 2012.

FLORESTA, Curitiba, PR, v. 51, n. 1, p. 201-210, jan/mar 2021.

Brand, M. A. et.al.

ISSN eletrônico 1982-4688

DOI: $10.5380 /$ rf.v51 i1. 67968 